\title{
The content of pigments in leaves of spinach and susceptibility of cultivars to black bean aphid (Aphis fabae Scop.) invasion
}

\author{
Poziom barwników w liściach szpinaku a podatność odmian \\ na zasiedlenie przez mszycę burakową (Aphis fabae Scop.)
}

\author{
Irena Łuczak ${ }^{1}$, Maria Gawęda ${ }^{2}$, Izabela Zdrójkowska ${ }^{1}$
}

\begin{abstract}
Summary
The differences in the content of green (chlorophyll $a+b$ ) and yellow-orange (carotenoids) pigments in the leaves of 7 cultivars of spinach (Spinacia oleracea L.) and New Zealand spinach (Tetragona expansa Murr.) and their effect on black bean aphid (Aphis fabae Scop.) invasion were investigated in 2007 and 2008. In both years, the largest numbers of total aphids and colonies were observed on the cultivar Olbrzym Zimowy, whereas, the fewest ones - on Tetragona expansa. The high percentages of plants infested by total aphids and winged migrants, and the largest numbers of winged aphids were found on two cultivars: Matador and Markiza. The cultivar Matador was characterised by the highest yellow-orange pigments content in leaves and the highest ratio of these pigments to green ones. In both years, on the cultivar Spiros $F_{1}$, small numbers of aphids and small percentages of infested plants were observed. The cultivar Spiros $F_{1}$ was characterized by the lowest content of pigments (chlorophyll $a+b$, carotenoids) in leaves. The influence of yellow-orange pigments on the $A$. fabae invasion was confirmed by the statistically significant and positive correlation coefficients between the carotenoids to chlorophyll $(a+b)$ ratio and the number of winged aphids and colonies, and also the percentages of infested plants by total aphids and winged migrants.
\end{abstract}

Key words: Aphis fabae, Spinacia oleracea, cultivars, Tetragona expansa, chlorophyll a and b, carotenoids, invasion

\section{Streszczenie}

W latach 2007 i 2008 badano różnice w zawartości barwników zielonych (chlorofil a + b) i żółtopomarańczowych (karotenoidy) w liściach 7 odmian szpinaku warzywnego (Spinacia oleracea L.) i szpinaku nowozelandzkiego (Tetragona expansa Murr.) oraz ich wpływ na zasiedlanie mszycy burakowej (Aphis fabae Scop.). W obydwu latach badań największe liczby wszystkich mszyc i kolonii były obserwowane na odmianie Olbrzym Zimowy, a najmniejsze - na Tetragona expansa. Wysokie procenty zasiedlanych roślin przez mszyce ogółem i uskrzydlone migrantki oraz największe liczby uskrzydlonych mszyc zostały wykazane na 2 odmianach: Matador i Markiza. Odmiana Matador charakteryzowała się najwyższą zawartością żółtopomarańczowych barwników w liściach i najwyższym wzajemnym stosunkiem tych barwników do barwników zielonych. W obydwu latach badań na odmianie Spiros $F_{1}$ obserwowano małe liczebności mszycy i niskie procenty zasiedlanych roślin. Odmiana Spiros $F_{1}$ charakteryzowała się najniższą zawartością barwników w liściach (chlorofil $a+b$, karotenoidy). Wpływ barwników żółtopomarańczowych na $A$. fabae potwierdziły statystycznie istotne i dodatnie współczynniki korelacji między wzajemnym stosunkiem karotenoidów do chlorofilu $(a+b)$ a liczbą uskrzydlonych mszyc i kolonii oraz procentem roślin zasiedlonych przez mszyce ogółem i uskrzydlone migrantki.

Słowa kluczowe: Aphis fabae, Spinacia oleracea, odmiany, Tetragona expansa, chlorofil a i b, karotenoidy, zasiedlanie

\footnotetext{
Uniwersytet Rolniczy im. Hugona Kołłątaja w Krakowie

Al. 29 Listopada 54, 31-425 Kraków

${ }^{1}$ Katedra Ochrony Roślin

i.luczak@ogr.ur.krakow.pl

${ }^{2}$ Katedra Roślin Warzywnych i Zielarskich

m.gaweda@ogr.ur.krakow.pl
} 


\section{Wstęp / Introduction}

Szpinak (Spinacia oleracea L.) jest warzywem bardzo popularnym i jego znaczenie gospodarcze w naszym kraju stale wzrasta. Rosną także wymagania dotyczące zdrowotności szpinaku przeznaczonego zarówno do bezpośredniej konsumpcji, jak i do mrożenia całych liści (muszą one być zdrowe i nieuszkodzone).

Najgroźniejszym szkodnikiem szpinaku jest mszyca burakowa (Aphis fabae Scop.). Kolonie mszycy są zakładane na dolnej stronie liści (głównie najmłodszych) i w wierzchniej części pędu. Opanowane rośliny tracą całkowicie wartość konsumpcyjną i handlową. Zmniejszenie szkodliwości mszycy byłoby możliwe przez wprowadzenie do uprawy odmian szpinaku słabo zasiedlanych przez uskrzydlone migrantki i w mniejszym stopniu kolonizowanych przez A. fabae.

Wstępne zasiedlanie roślin przez migrujące mszyce jest związane przede wszystkim z podrażnieniem receptorów wzrokowych (Kennedy i wsp. 1961; Kring 1967; Coon i Pepper 1968). Jednym z głównych bodźców wpływających na ten proces jest barwa liści (David i Hardie 1988; Hardie i wsp. 1989; Nottingham i Hardie 1989). Natężenie zielonej barwy liści zależy od zawartości barwników roślinnych, głównie żółtopomarańczowych (obejmujących flawonole i karoteny), a także zielonych (chlorofile a i b) oraz wzajemnych proporcji między nimi (Leszczyński i wsp. 1985; Leszczyński 1987). W badaniach Gawędy i Łuczak (1993) stwierdzono dodatnie i statystycznie istotne korelacje między zawartością w liściach buraka cukrowego karotenoidów i chlorofili oraz tzw. wskaźnikiem barwy (wyrażającym wzajemny stosunek karotenoidy: chlorofile) a parametrami zasiedlania roślin przez mszycę burakową. Podobne zależności między wskaźnikiem barwy a liczbą uskrzydlonych migrantek $A$. fabae wykazano na buraku ćwikłowym (Luczak i Gawęda 1991a). Łuczak (1993) obserwowała różnice (między czterema badanymi odmianami szpinaku) w średniej liczbie uskrzydlonych form $A$. fabae i stwierdziła dodatnią korelację między tym parametrem a stosunkiem karotenoidy:suma chlorofilu a i b.

Celem badań było porównanie wpływu siedmiu odmian szpinaku warzywnego (Spinacia oleracea L.) oraz szpinaku nowozelandzkiego (Tetragona expansa Murr.) na osiadanie na roślinach uskrzydlonych mszyc $A$. fabae i ich kolonizację. Podjęto także próbę wyjaśnienia roli barwników roślinnych w słabszym zasiedlaniu niektórych odmian $S$. oleracea i $T$. expansa przez uskrzydlone migrantki mszycy burakowej.

\section{Materiały i metody / Materials i methods}

Badania prowadzono w latach 2007-2008 na polu doświadczalnym Uniwersytetu Rolniczego, w Mydlnikach koło Krakowa. Testowaniem objęto 7 odmian szpinaku warzywnego - Spinacia oleracea L. i szpinak nowozelandzki - Tetragona expansa Murr. (tab. 1, 2). Doświadczenie odmianowe założono w układzie bloków losowanych w czterech powtórzeniach; powierzchnia pojedynczego poletka wynosiła $5,2 \mathrm{~m}^{2}(2,5 \times 2,1 \mathrm{~m})$. Nasiona szpinaku zostały wysiane 05.05.2007 oraz 25.04.2008 w rzędach odległych co $35 \mathrm{~cm}$.

Od momentu pojawienia się na szpinaku uskrzydlonych migrantek i pierwszych kolonii A. fabae (aż do całkowitego zaniku mszyc) prowadzono średnio co 4 dni bezpośrednie obserwacje liczebności mszycy na roślinach. Obserwacjami objęto po 100 roślin z każdego poletka. Wytypowano je (i odpowiednio oznakowano) ze środkowych rzędów poletek podczas wykonywania pierwszej obserwacji, tj. 05.06.2007 oraz 31.05.2008. Na oznakowanych roślinach każdorazowo przeglądano wszystkie liście i liczono dokładnie obecne na nich mszyce. Notowano samice uskrzydlone i bezskrzydłe oraz nimfy, a także liczbę kolonii i zagęszczenie mszyc w koloniach. Rośliny opanowane przez $A$. fabae każdorazowo etykietowano. Zasiedlanie (przez mszycę) badanych odmian szpinaku warzywnego i szpinaku nowozelandzkiego charakteryzowano na podstawie kilku obliczonych wskaźników (tab. 1). Istotność różnic określano według testu t-Studenta $(\mathrm{p}=0,05)$.

Równolegle z obserwacjami entomologicznymi wykonywano oznaczenia zawartości w liściach barwników roślinnych: zielonych (chlorofil a, chlorofil b) i żółtopomarańczowych (karotenoidy). Analizy chemiczne wykonano po okresie masowego pojawienia się na szpinaku uskrzydlonych migrantek $A$. fabae, tj. w trzeciej i w drugiej dekadzie czerwca (odpowiednio - w 2007 i 2008 r.). Zawartość barwników określano w świeżych liściach według procedury podanej przez Lichtenthalera i Wellburna (1983). Do oznaczeń chemicznych (dla każdej odmiany) pobierano próby liści z 20 roślin nie opanowanych przez $A$. fabae i spoza środkowych rzędów poletek. Po umyciu, liście suszono na bibule filtracyjnej, a następnie wycinano $\mathrm{z}$ nich krążki o średnicy $5 \mathrm{~mm}$. Po odważeniu (dla danej odmiany) trzech prób reprezentatywnych o wadze $250 \mathrm{mg}$ każda, wycięte $z$ liści krążki rozcierano w moździeżu i ekstrahowano $80 \%$ acetonem. Absorbcję roztworów mierzono przy następujących długościach fal: chlorofil a - 663, chlorofil b - 646, karotenoidy - $470 \mathrm{~nm}$. Zależności pomiędzy zawartością w liściach barwników zielonych i żółtopomarańczowych a analizowanymi wskaźnikami zasiedlania roślin przez $A$. fabae określano za pomocą obliczonych współczynników korelacji prostej „r” Pearsona.

\section{Wyniki i dyskusja / Results and discussion}

Liczby mszyc i kolonii oraz procenty zasiedlonych roślin przez $A$. fabae były różne w dwóch kolejnych latach i zależały od odmiany szpinaku warzywnego oraz gatunku rośliny: S. oleracea lub $T$. expansa. Różnice w dynamice nalatywania i kolonizowania roślin uprawnych przez A. fabae oraz wielkości powodowanych przez nią szkód w zależności od roku, gatunku rośliny i odmiany są dyskutowane w wielu pracach (Hurej 1991; Łuczak 1991; Goszczyński i wsp. 1992; Łuczak 1996a, b, c, 2010; Łuczak i wsp. 2012).

W 2007 r. pierwsze uskrzydlone migrantki $A$. fabae i pojedyncze słabe kolonie (1 lub 2 na poletku) zaobserwowano na szpinaku warzywnym w dniu 5 czerwca. Migrantki były notowane do 18.06 lub 22.06.2007 (za- 
Tabela 1. Wskaźniki charakteryzujące zasiedlenie wybranych odmian szpinaku warzywnego (S. oleracea) i szpinaku nowozelandzkiego (T. expansa) przez mszyce burakowa (A. fabae) w latach 2007-2008

Table 1. Infestation indices of selected cultivars of spinach (S. oleracea) and New Zealand spinach (T. expansa) by black bean aphid (A. fabae) in 2007-2008

\begin{tabular}{|c|c|c|c|c|c|c|c|c|c|c|}
\hline \multirow{3}{*}{$\begin{array}{l}\text { Gatunek, } \\
\text { odmiana } \\
\text { Species, } \\
\text { cultivar }\end{array}$} & \multirow{3}{*}{$\begin{array}{l}\text { Rok } \\
\text { Year }\end{array}$} & \multirow{2}{*}{\multicolumn{3}{|c|}{$\begin{array}{c}\text { Średnia liczba mszyc i kolonii } \\
\text { na } 1 \text { poletku w okresie obserwacji } \\
\text { Mean number of aphids and } \\
\text { colonies on } 1 \text { plot during } \\
\text { observation period }\end{array}$}} & \multicolumn{4}{|c|}{$\begin{array}{l}\% \text { roślin zasiedlonych przez: } \\
\% \text { of plants infested by: }\end{array}$} & \multirow{2}{*}{\multicolumn{2}{|c|}{$\begin{array}{l}\text { Maksymalna } \\
\text { liczba kolonii } \\
\text { Maximum number } \\
\text { of colonies }\end{array}$}} \\
\hline & & & & & \multicolumn{2}{|c|}{$\begin{array}{l}\text { mszyce ogółem } \\
\text { total aphids }\end{array}$} & \multicolumn{2}{|c|}{$\begin{array}{l}\text { uskrzydlone } \\
\text { winged }\end{array}$} & & \\
\hline & & $\begin{array}{l}\text { mszyce } \\
\text { ogółem } \\
\text { total } \\
\text { aphids }\end{array}$ & $\begin{array}{l}\text { uskrzyd- } \\
\text { lone } \\
\text { winged }\end{array}$ & $\begin{array}{l}\text { kolonie } \\
\text { colonies }\end{array}$ & $\begin{array}{l}\text { w całym } \\
\text { okresie } \\
\text { at whole } \\
\text { period }\end{array}$ & $\begin{array}{c}\text { w terminie } \\
\text { maksimum } \\
\text { in maximum } \\
\text { date }\end{array}$ & $\begin{array}{l}\text { w całym } \\
\text { okresie } \\
\text { at whole } \\
\text { period }\end{array}$ & $\begin{array}{c}\text { w terminie } \\
\text { maksimum } \\
\text { at maximum } \\
\text { date }\end{array}$ & $\begin{array}{c}\text { na } 1 \\
\text { roślinie } \\
\text { per 1 plant }\end{array}$ & $\begin{array}{c}\text { w } 1 \\
\text { terminie } \\
\text { in one day }\end{array}$ \\
\hline $\begin{array}{l}\text { Spinacia } \\
\text { oleracea }\end{array}$ & & & & & & & & & & \\
\hline $\begin{array}{l}\text { Olbrzym } \\
\text { Zimowy }\end{array}$ & $\begin{array}{c}2007 \\
2008 \\
\text { średnio } \\
\text { mean }\end{array}$ & $\begin{array}{l}269,5 \\
989,5 \\
629,5\end{array}$ & $\begin{array}{l}4,5 \\
4,0 \\
4,2\end{array}$ & $\begin{array}{l}23,5 \\
81,5 \\
52,5\end{array}$ & $\begin{array}{l}17,0 \\
47,5 \\
32,2\end{array}$ & $\begin{array}{r}5,0 \\
20,0 \\
12,5\end{array}$ & $\begin{array}{l}4,0 \\
3,0 \\
3,5\end{array}$ & $\begin{array}{l}1,0 \\
1,5 \\
1,2\end{array}$ & $\begin{array}{l}5 \\
5 \\
5,0\end{array}$ & $\begin{array}{l}11 \\
37 \\
24,0\end{array}$ \\
\hline Orbita & $\begin{array}{c}2007 \\
2008 \\
\text { średnio } \\
\text { mean }\end{array}$ & $\begin{array}{l}141,0 \\
696,5 \\
418.7\end{array}$ & $\begin{array}{l}6,5 \\
3,0 \\
4.7\end{array}$ & $\begin{array}{l}24,0 \\
39,0 \\
31,5\end{array}$ & $\begin{array}{l}20,0 \\
26,5 \\
23,2\end{array}$ & $\begin{array}{l}4,5 \\
9,5 \\
7,0\end{array}$ & $\begin{array}{l}6,5 \\
5,5 \\
6,0\end{array}$ & $\begin{array}{l}1,5 \\
2,0 \\
1,7\end{array}$ & $\begin{array}{l}4 \\
4 \\
4.0\end{array}$ & $\begin{array}{c}7 \\
18 \\
12,5\end{array}$ \\
\hline Greta & $\begin{array}{c}2007 \\
2008 \\
\text { średnio } \\
\text { mean }\end{array}$ & $\begin{array}{r}99,0 \\
688,0 \\
393,5\end{array}$ & $\begin{array}{l}5,5 \\
3,5 \\
4,5\end{array}$ & $\begin{array}{l}23,0 \\
51,5 \\
37,2\end{array}$ & $\begin{array}{l}20,0 \\
40,5 \\
30,2\end{array}$ & $\begin{array}{r}5,0 \\
15,5 \\
10,2\end{array}$ & $\begin{array}{l}4,5 \\
3,5 \\
4,0\end{array}$ & $\begin{array}{l}1,0 \\
2,5 \\
1,7\end{array}$ & $\begin{array}{l}3 \\
3 \\
3,0\end{array}$ & $\begin{array}{c}6 \\
20 \\
13,0\end{array}$ \\
\hline $\begin{array}{l}\text { Rembrandt } \\
\mathrm{F}_{1}\end{array}$ & $\begin{array}{c}2007 \\
2008 \\
\text { średnio } \\
\text { mean }\end{array}$ & $\begin{array}{r}87,0 \\
606,0 \\
346,5\end{array}$ & $\begin{array}{l}6,0 \\
7,0 \\
6,5\end{array}$ & $\begin{array}{l}16,5 \\
51,5 \\
34,0\end{array}$ & $\begin{array}{l}16,0 \\
37,0 \\
26,5\end{array}$ & $\begin{array}{r}4,0 \\
18.0 \\
11,0\end{array}$ & $\begin{array}{l}5,0 \\
6,0 \\
5,5\end{array}$ & $\begin{array}{l}1.5 \\
2,5 \\
2,0\end{array}$ & $\begin{array}{l}2 \\
4 \\
3,0\end{array}$ & $\begin{array}{c}5 \\
27 \\
16,0\end{array}$ \\
\hline Markiza & $\begin{array}{c}2007 \\
2008 \\
\text { średnio } \\
\text { mean }\end{array}$ & $\begin{array}{l}124,5 \\
365,0 \\
244,7\end{array}$ & $\begin{array}{r}13,5 \\
2,5 \\
8,0\end{array}$ & $\begin{array}{l}29,0 \\
42,5 \\
35,7\end{array}$ & $\begin{array}{l}27,0 \\
34,5 \\
30,7\end{array}$ & $\begin{array}{r}6,5 \\
19,0 \\
12,7\end{array}$ & $\begin{array}{r}11,0 \\
1,8 \\
6,4\end{array}$ & $\begin{array}{l}4,0 \\
1,0 \\
2,5\end{array}$ & $\begin{array}{l}4 \\
3 \\
3,5\end{array}$ & $\begin{array}{c}7 \\
24 \\
15,5\end{array}$ \\
\hline Matador & $\begin{array}{c}2007 \\
2008 \\
\text { średnio } \\
\text { mean }\end{array}$ & $\begin{array}{r}64,5 \\
319,5 \\
192,0\end{array}$ & $\begin{array}{l}6,0 \\
9,5 \\
7,7\end{array}$ & $\begin{array}{l}16,0 \\
58,0 \\
37,0\end{array}$ & $\begin{array}{l}15,5 \\
41,0 \\
28,2\end{array}$ & $\begin{array}{r}3,0 \\
23,0 \\
13,0\end{array}$ & $\begin{array}{l}5,5 \\
8,5 \\
7,0\end{array}$ & $\begin{array}{l}1,0 \\
5,8 \\
3,4\end{array}$ & $\begin{array}{l}2 \\
5 \\
3,5\end{array}$ & $\begin{array}{l}3 \\
35 \\
19,0\end{array}$ \\
\hline Spiros $F_{1}$ & $\begin{array}{c}2007 \\
2008 \\
\text { średnio } \\
\text { mean }\end{array}$ & $\begin{array}{r}57,5 \\
271,0 \\
164,2\end{array}$ & $\begin{array}{l}5,0 \\
1,5 \\
3,2\end{array}$ & $\begin{array}{l}13,5 \\
29,0 \\
21,2\end{array}$ & $\begin{array}{l}13,0 \\
26,5 \\
19,7\end{array}$ & $\begin{array}{r}3,5 \\
10,5 \\
7,0\end{array}$ & $\begin{array}{l}4,4 \\
1,5 \\
3,0\end{array}$ & $\begin{array}{l}2,0 \\
1,0 \\
1,5\end{array}$ & $\begin{array}{l}2 \\
2 \\
2,0\end{array}$ & $\begin{array}{c}4 \\
13 \\
8,5\end{array}$ \\
\hline $\begin{array}{l}\text { Tetragona } \\
\text { expansa }\end{array}$ & $\begin{array}{c}2007 \\
2008 \\
\text { średnio } \\
\text { mean }\end{array}$ & $\begin{array}{l}18,0 \\
38,5 \\
28,2\end{array}$ & $\begin{array}{l}3,0 \\
0,5 \\
1,7\end{array}$ & $\begin{array}{l}6,0 \\
8,0 \\
7,0\end{array}$ & $\begin{array}{l}6,0 \\
7,5 \\
6,7\end{array}$ & $\begin{array}{l}1,5 \\
3,5 \\
2,5\end{array}$ & $\begin{array}{l}3,0 \\
0,5 \\
1,7\end{array}$ & $\begin{array}{l}0,5 \\
0,5 \\
0,5\end{array}$ & $\begin{array}{l}1 \\
2 \\
1,5\end{array}$ & $\begin{array}{l}2 \\
4 \\
3,0\end{array}$ \\
\hline $\begin{array}{l}\operatorname{NIR}(0,05) \\
\operatorname{LSD}(0.05)\end{array}$ & $\begin{array}{c}2007 \\
2008 \\
\text { średnio } \\
\text { mean }\end{array}$ & $\begin{array}{r}46,01 \\
548,17 \\
259,35\end{array}$ & $\begin{array}{l}3,03 \\
3,37 \\
3,51\end{array}$ & $\begin{array}{r}3,90 \\
15,08 \\
19,99\end{array}$ & $\begin{array}{r}1,95 \\
4,18 \\
14,39\end{array}$ & $\begin{array}{l}0,83 \\
3,06 \\
4,96\end{array}$ & $\begin{array}{l}2,50 \\
2,15 \\
3,07\end{array}$ & $\begin{array}{l}0,73 \\
1,72 \\
1,42\end{array}$ & $\begin{array}{l}1,25 \\
0,79 \\
1,92\end{array}$ & $\begin{array}{l}2,19 \\
5,83 \\
8,89\end{array}$ \\
\hline
\end{tabular}

leżnie od odmiany) i kolonizowały one rośliny $S$. oleracea w niejednakowym stopniu. Populacja $A$. fabae była największa (średnio na 1 poletku w całym okresie obserwacji - 269,5 mszyc) na odmianie Olbrzym Zimowy (tab. 1). Tutaj, w dniu 2 lipca (tj. w terminie maksymalnego pojawu mszycy) stwierdzono największe liczby kolonii: na 1 roślinie -5 , na 1 poletku -11 . Wartości tych trzech obliczonych wskaźników różniły się zasadniczo i statystycznie istotnie od wartości otrzymanych dla pozostałych odmian. W omawianym roku (2007) na roślinach $S$. oleracea obserwowano pojedyncze mszyce (1-5 szt.) oraz słabe (6-12 szt.) i średnie kolonie (13-42 mszyc/roślinie). Na 2 odmianach (Olbrzym Zimowy i Orbita) notowano także obecność silnych kolonii (tj. 43-120 mszyc/roślinie). Skalę liczebności mszyc w koloniach podano za Goosem (1966). Obecność silnych kolonii na szpinaku Olbrzym Zimowy i prawie 100\% zasiedlonych roślin (w 1989 r.) wykazała Łuczak (1993). 
W 2007 r. najwięcej uskrzydlonych migrantek (średnio na 1 poletku - 13,5 szt.) i największą liczbę kolonii (w całym okresie na 1 poletku - 29) stwierdzono na szpinaku Markiza (tab. 1). Tutaj, zarówno w terminie maksimum występowania mszycy (02.07), jak i w całym okresie obserwacji notowane były największe procenty zasiedlonych roślin przez mszyce ogółem i przez uskrzydlone migrantki. Wszystkie obliczone wskaźniki zasiedlenia roślin przez $A$. fabae były w 2007 roku istotnie zróżnicowane między odmianami szpinaku warzywnego, a także między roślinami $S$. oleracea i $T$. expansa. Na szpinaku nowozelandzkim pierwsze uskrzydlone samice A. fabae zaobserwowano 18 czerwca; pojedyncze ich okazy wraz z nielicznymi larwami $\mathrm{L}_{1}-\mathrm{L}_{3}$ (maksymalnie 8 szt./roślinie) notowano do 6 lipca. Na $T$. expansa nie obserwowano w ogóle bezskrzydłych dzieworodnych samic, ani starszych larw ( $\left.\mathrm{L}_{4} \mathrm{i}_{\mathrm{L}} \mathrm{L}_{5}\right)$ mszycy. Można przypuszczać, że czynnikami które hamowały proces żerowania i rozwój mszycy na szpinaku nowozelandzkim mogły być zarówno właściwości budowy morfologicznej i anatomicznej roślin (grube, szorstkie i twarde liście), jak i ich skład biochemiczny. Niższy poziom cukrowców rozpuszczalnych (zwłaszcza sacharozy) i przyswajalnych form azotu (azot ogólny, azot białkowy) stwierdzono w liściach odmian buraków bardziej odpornych na badaną mszycę (Łuczak i Gawęda 1991b, 1993).

W 2008 r. populacja mszycy na szpinaku warzywnym (S. oleracea) była zdecydowanie większa, aniżeli w pierwszym roku badań. Łączne liczby mszyc przekraczały 3- lub 5-krotnie (zależnie od odmiany) wartości otrzymane w 2007 roku (tab. 1). Dla niektórych odmian (np. Olbrzym Zimowy, Rembrandt $F_{1}$ i Matador) także liczby rozwiniętych kolonii były 3-krotnie większe, aniżeli w roku poprzednim. Nalot uskrzydlonych migrantek na rośliny S. oleracea trwał krótko (od 31.05 do 09.06.2008) i nie był liczny. Bardzo silne rozmnożenie się mszycy i maksymalny pojaw szkodnika zaobserwowano 6 lub 9 czerwca; po tym terminie liczebność $A$. fabae gwałtownie zmalała, a całkowity zanik mszyc odnotowano 2 lipca. Obliczone (dla całego okresu obserwacji) średnie liczby mszyc i kolonii przypadające na 1 poletko były największe (podobnie, jak w 2007 r.) na szpinaku Olbrzym Zimowy. Wartości te wynosiły - 989,5 mszyc oraz 81,5 kolonii (tab. 1). Tutaj, procenty zasiedlonych roślin przez mszyce ogółem oraz maksymalne zagęszczenia kolonii (na roślinie i na poletku) posiadały również wartości najwyższe.

W 2008 r. najwięcej uskrzydlonych migrantek (średnio 9,5 szt. na 1 poletku), wysoką liczbę kolonii (58 na 1 poletku) oraz wysokie procenty roślin zasiedlonych przez mszyce ogółem i uskrzydlone migrantki obserwowano na szpinaku Matador. Na szpinaku nowozelandzkim (T. expansa) populacja mszycy burakowej była (podobnie, jak w roku poprzednim) wielokrotnie mniejsza aniżeli na S. oleracea. Tutaj, obecność pojedynczych mszyc (1-5 szt.) bądź słabych kolonii (6-12 szt./roślinie) notowano w trzech terminach: 2.06, 6.06 i 9.06. Na T. expansa stwierdzano głównie młodociane stadia (nimfy) $A$. fabae. Bezskrzydłe dzieworodne samice były nieliczne, a 2 okazy uskrzydlonych samic zanotowano w dniu 9 czerwca.
Średnie (obliczone za 2 lata) wartości wskaźników i przeprowadzona analiza istotności pozwala wnioskować, że badane odmiany szpinaku warzywnego (S. oleracea) stwarzają znacznie bardziej korzystne warunki do zasiedlania przez $A$. fabae, aniżeli rośliny szpinaku nowozelandzkiego ( $T$. expansa). Pomimo zaobserwowanych (w latach badań) różnic w liczebności mszyc nalatujących i kolonizujących rośliny szpinaku preferencja testowanych odmian była dość stabilna. Największą atrakcyjnością na badaną mszycę charakteryzowała się odmiana Olbrzym Zimowy. Zbliżone wyniki uzyskała we wcześniejszych badaniach Łuczak (1993). Spośród testowanych odmian (w latach 2007-2008) Markiza i Matador przyciągały najsilniej uskrzydlone migrantki $A$. fabae i były przez nie zasiedlane najczęściej. Niskim stopniem akceptacji (wobec mszycy) w procesie zasiedlania roślin charakteryzowała się odmiana mieszańcowa Spiros $F_{1}$. Uzyskane wyniki mogą stanowić ważną informację dla hodowli odpornościowej Spinacia oleracea wobec najgroźniejszego fitofaga, tj. mszycy burakowej. Wskazuja one także na potrzebę analizowania tych cech odmianowych szpinaku (morfologicznych i biochemicznych), które nie sprzyjają zasiedlaniu roślin przez uskrzydlone migrantki i ich kolonizacji. Jedną $\mathrm{z}$ przyczyn różnego zasiedlania roślin przez uskrzydlone mszyce mogą być różnice odmianowe związane $\mathrm{z}$ natężeniem zielonej barwy liści. Prokopy i Owens (1983) wyjaśniają, że różne natężenie zielonej barwy liści (i związane $z$ tym oddziaływanie na receptory wzrokowe mszyc) zależy od zawartości podstawowych grup barwników roślinnych: zielonych, żółtych i pomarańczowych.

Średnie (za 2 lata) zawartości barwników liściowych były istotnie zróżnicowane między odmianami szpinaku warzywnego oraz między $S$. oleracea i $T$. expansa (tab. 2). $\mathrm{Z}$ porównania danych zamieszczonych $\mathrm{w}$ tabelach 1 . i 2. wynika, że największy pozytywny wpływ na zasiedlanie roślin szpinaku przez $A$. fabae wywiera poziom zawartych w liściach karotenoidów oraz wzajemny stosunek zawartości tych barwników do zielonych chlorofili (tzw. wskaźnik barwy). Istotnie, w liściach szpinaku Matador (o najwyższych wskaźnikach zasiedlania roślin przez uskrzydlone migrantki $A$. fabae) stwierdzono najwyższy poziom karotenoidów $(0,209 \mathrm{mg} / \mathrm{g})$ i uzyskano najwyższą wartość tzw. wskaźnika barwy (karotenoidy:suma chlorofilu $\mathrm{a}+\mathrm{b}=0,248)$. Liście mieszańcowej odmiany Rembrandt $\mathrm{F}_{1}$ (często zasiedlanej przez uskrzydlone migrantki, lecz słabiej kolonizowanej przez $A$. fabae) zawierały najwięcej chlorofilu a + b $(1,019 \mathrm{mg} / \mathrm{g})$ i wysoki poziom karotenoidów $(0,199 \mathrm{mg} / \mathrm{g})$. Zawartości te przekraczały 3-krotnie poziom barwników asymilacyjnych w liściach odmiany Spiros $\mathrm{F}_{1}$ - o najniższych wskaźnikach zasiedlania roślin przez badaną mszycę. Średni poziom chlorofili i karotenoidów stwierdzono w liściach szpinaku nowozelandzkiego (o bardzo niskiej populacji mszycy).

Wykazano dodatnie zależności pomiędzy zawartością w liściach chlorofili i karotenoidów oraz wzajemnym stosunkiem karotenoidy:suma chlorofilu a + b (tzw. wskaźnikiem barwy) a badanymi parametrami zasiedlania 
Tabela 2. Zawartość barwników zielonych i żółtopomarańczowych [mg/g świeżej masy] w liściach badanych odmian szpinaku warzywnego (S. oleracea) i szpinaku nowozelandzkiego (T. expansa) - wartości średnie za lata 2007-2008

Table 2. The content of green and yellow-orange pigments $[\mathrm{mg} / \mathrm{g}$ fresh weight $]$ in leaves of tested cultivars of spinach $(S$. oleracea $)$ and New Zealand spinach (T. expansa) - mean values from 2007-2008

\begin{tabular}{|c|c|c|c|c|c|}
\hline $\begin{array}{l}\text { Gatunek, } \\
\text { odmiana } \\
\text { Species, } \\
\text { cultivar }\end{array}$ & $\begin{array}{l}\text { Chlorofil a } \\
\text { Chlorophyll a }\end{array}$ & $\begin{array}{l}\text { Chlorofil b } \\
\text { Chlorophyll b }\end{array}$ & $\begin{array}{c}\text { Suma } \\
\text { chlorofilu } \\
a+b \\
\text { Chlorophyll } \\
a+b\end{array}$ & $\begin{array}{l}\text { Karotenoidy } \\
\text { Carotenoids }\end{array}$ & $\begin{array}{c}\text { Karotenoidy: } \\
\text { suma } \\
\text { chlorofilu a }+\mathrm{b} \\
\text { Carotenoids: } \\
\text { chlorophylls } \\
\mathrm{a}+\mathrm{b}\end{array}$ \\
\hline \multicolumn{6}{|l|}{ Spinacia oleracea } \\
\hline Olbrzym Zimowy & 0,666 & 0,183 & 0,849 & 0,181 & 0,213 \\
\hline Orbita & 0,731 & 0,203 & 0,934 & 0,191 & 0,204 \\
\hline Greta & 0,644 & 0,177 & 0,821 & 0,172 & 0,209 \\
\hline Rembrandt $\mathrm{F}_{1}$ & 0,787 & 0,232 & 1,019 & 0,199 & 0,195 \\
\hline Markiza & 0,682 & 0,186 & 0,868 & 0,196 & 0,226 \\
\hline Matador & 0,665 & 0,179 & 0,844 & 0,209 & 0,248 \\
\hline Spiros $F_{1}$ & 0,269 & 0,063 & 0,332 & 0,076 & 0,229 \\
\hline Tetragona expansa & 0,734 & 0,218 & 0,952 & 0,194 & 0,204 \\
\hline $\operatorname{NIR}(0,05)-\operatorname{LSD}(0.05)$ & 0,0851 & 0,0379 & 0,0608 & 0,0149 & 0,0100 \\
\hline
\end{tabular}

Tabela 3. Współczynniki korelacji „r” między zawartością w liściach szpinaku (S. oleracea, T. expansa) barwników zielonych (chlorofil $\mathrm{a}+\mathrm{b})$ i żółtopomarańczowych (karotenoidy) a zasiedleniem roślin przez mszycę $A$. fabae (wartości średnie dla 8 odmian i 2 lat)

Table 3. The coefficients of correlation between the content of green (chlorophyll a $+\mathrm{b}$ ) and yellow-orange (carotenoids) pigments in leaves of spinach (S. oleracea, T. expansa) and the infestation of plants by A. fabae (mean values for 8 cultivars and 2 years)

\begin{tabular}{|c|c|c|c|}
\hline $\begin{array}{l}\text { Badane parametry zasiedlania roślin } \\
\text { Studied parameters of plant infestation }\end{array}$ & $\begin{array}{l}\text { Suma chlorofilu a }+\mathrm{b} \\
\text { Chlorophyll } \mathrm{a}+\mathrm{b}\end{array}$ & $\begin{array}{l}\text { Karotenoidy } \\
\text { Carotenoids }\end{array}$ & $\begin{array}{l}\text { Karotenoidy: } \\
\text { suma chlorofilu } \mathrm{a}+\mathrm{b} \\
\text { Carotenoids: } \\
\text { chlorophylls } \mathrm{a}+\mathrm{b}\end{array}$ \\
\hline $\begin{array}{l}\text { Średnia liczba mszyc uskrzydlonych } \\
\text { na } 1 \text { poletku } \\
\text { Mean number of winged on } 1 \text { plot }\end{array}$ & 0,299 & 0,451 & $0,509 *$ \\
\hline $\begin{array}{l}\text { Maksymalna liczba kolonii na poletku } \\
\text { w } 1 \text { terminie } \\
\text { Maximum number of colonies on plot } \\
\text { in one day }\end{array}$ & 0,225 & 0,384 & $0,520^{*}$ \\
\hline $\begin{array}{l}\text { Maksymalna liczba kolonii na } 1 \text { roślinie } \\
\text { Maximum number of colonies per } 1 \text { plant }\end{array}$ & 0,422 & $0,541^{*}$ & 0,270 \\
\hline $\begin{array}{l}\text { Maksymalny \% roślin zasiedlonych } \\
\text { przez mszyce ogółem } \\
\text { Maximum percentage of plants infested } \\
\text { by total aphids }\end{array}$ & 0,124 & 0,311 & $0,608^{*}$ \\
\hline $\begin{array}{l}\text { Maksymalny \% roślin zasiedlonych } \\
\text { przez mszyce uskrzydlone } \\
\text { Maximum percentage of plants infested } \\
\text { by winged }\end{array}$ & 0,282 & 0,447 & $0,543 *$ \\
\hline $\begin{array}{l}\text { Średni \% roślin zasiedlonych } \\
\text { przez mszyce ogółem } \\
\text { Mean percentage of plants infested } \\
\text { by total aphids }\end{array}$ & 0,039 & 0,140 & 0,352 \\
\hline $\begin{array}{l}\text { Średni \% roślin zasiedlonych } \\
\text { przez mszyce uskrzydlone } \\
\text { Mean percentage of plants infested } \\
\text { by winged }\end{array}$ & 0,320 & 0,457 & 0,439 \\
\hline
\end{tabular}

$\mathrm{r}_{\text {teor. }}(\mathrm{p}=0,05)-\mathrm{r}_{\text {theor. }}(\mathrm{p}=0.05)-0,497$

$r_{\text {teor. }}(p=0,01)-r_{\text {theor. }}(p=0.01)-0,623$

*korelacja statystycznie istotna przy $\mathrm{p}=0,05$ - correlation statistically significant at $\mathrm{p}=0.05$ 
szpinaku przez A. fabae. (tab. 3). Podobne zależności wykazano na buraku cukrowym (Gawęda i Łuczak 1993).

Na podstawie obliczonych wartości „r” (tab. 3) można wnioskować, że przyciąganie uskrzydlonych migrantek A. fabae do roślin szpinaku zależy od barwy liści i jest modyfikowane przez poziom barwników żółtopomarańczowych. Potwierdzają to wysokie dodatnie i statystycznie istotne korelacje pomiędzy wskaźnikiem barwy (wyrażającym stosunek zawartości karotenoidów do chlorofili) a liczbą uskrzydlonych mszyc i kolonii oraz maksymalnym zasiedleniem roślin (\%) przez mszyce ogółem i uskrzydlone migrantki. Podobne zależności obserwowano na buraku ćwikłowym (Łuczak i Gawęda 1991a) i we wcześniejszych badaniach Łuczak (1993) na szpinaku. Wpływ barwników roślinnych (zielonych i żółtopomarańczowych) na zasiedlanie przez Sitobion avenae (F.) odmian pszenicy ozimej badali również Leszczyński i wsp. (1985) oraz Leszczyński (1987). Autorzy ci sugerują, że najprawdopodobniej to flawonole (posiadające intensywny żółty kolor i wykazujące żółtozieloną fluorescencję) oddziaływują na receptory wzrokowe mszyc i przyciagają uskrzydlone migrantki. Leszczyński (1987) uważa, że dobrym kryterium do określania akceptacji roślin przez uskrzydlone mszyce jest tzw. wskaźnik barwy. Niskie wartości wzajemnego stosunku karotenoidy:suma chlorofilu $\mathrm{a}+\mathrm{b}$ (tj. wskaźnika barwy) wykazano dla 3 odmian szpinaku warzywnego (Rembrandt $\mathrm{F}_{1}$, Orbita, Greta) oraz dla T. expansa (tab. 2).

\section{Wnioski / Conclusions}

1. Rośliny szpinaku warzywnego (S. oleracea) są znacznie częściej zasiedlane (przez mszycę $A$. fabae) aniżeli szpinak nowozelandzki ( $T$. expansa). $\mathrm{Na}$ szpinaku nowozelandzkim obserwuje się głównie pojedyncze okazy mszyc (uskrzydlone samice i nimfy $\mathrm{L}_{1}-\mathrm{L}_{3}$ ) lub słabe kolonie.

2. Największą populację A. fabae (łączna liczba mszyc i kolonii) oraz najwięcej zasiedlonych roślin (w \%) przez mszyce ogółem obserwuje się na odmianie Olbrzym Zimowy. Najwięcej uskrzydlonych migrantek oraz wysokie procenty roślin zasiedlonych przez mszyce ogółem i uskrzydlone migrantki są notowane na 2 odmianach szpinaku (Matador i Markiza).

3. Odmiana Matador charakteryzuje się najwyższą zawartością w liściach barwników żółtopomarańczowych (karotenoidy) oraz najwyższą wartością wzajemnego stosunku karotenoidów do barwników zielonych (chlorofil $\mathrm{a}+\mathrm{b}$ ).

4. Liście heterozyjnego mieszańca Spiros $F_{1}$ zawierają najniższy poziom barwników zielonych (chlorofil a, chlorofil b) i żółtopomarańczowych (karotenoidy). Na tej odmianie prawie wszystkie wskaźniki charakteryzujące zasiedlanie (przez A. fabae) posiadają wartości najniższe.

5. Istnieje dodatnia i statystycznie istotna korelacja pomiędzy wzajemnym stosunkiem karotenoidów do chlorofilu $(\mathrm{a}+\mathrm{b})$ a liczbą uskrzydlonych mszyc i kolonii oraz procentem zasiedlonych roślin przez mszyce ogółem i uskrzydlone migrantki $A$. fabae.

\section{Literatura / References}

Coon B.F., Pepper J.B. 1968. Alate aphid species captured in yellow pans. J. Econ. Entomol. 61: 1472-1473.

David C.T., Hardie J. 1988. The visual responses of free-flying summer and autumn forms of the black bean aphid, Aphis fabae, in an automated flight chamber. Physiol. Entomol. 13 (3): 277-284.

Gawęda M., Luczak I. 1993. The role of chemical factors in sugar beet resistance to invasion by black bean aphid Aphis fabae. IOBC/WPRS Bull. 16 (5): 185-191.

Goos A. 1966. Metodyka ilościowego określania nasilenia mszyc w doświadczeniach polowej oceny insektycydów. Ekologia Polska, Ser. B, 12: 357-361.

Goszczyński W., Cichocka E., Chacińska M. 1992. Aphis fabae (Scop.) on field beans (Vicia faba sp. minor) - life cycle and the direct harmfulness. Aphids and Other Homopterous Insects 3: 51-57.

Hardie J., Poppy G.M., David C.T. 1989. Visual responses of flying aphids and their chemical modification. Physiol. Entomol. 14 (1): 41-51.

Hurej M. 1991. Reakcja Buraka Cukrowego na Żerowanie Mszycy Burakowej (Aphis fabae Scop.). Mszyce - ich Bionomia, Szkodliwość i Wrogowie Naturalni. PAN, Warszawa: 23-30.

Kennedy J.S., Booth C.D., Kershaw W.J.S. 1961. Host finding by aphids in the field. III. Visual attraction. Ann. Appl. Biol. 49: 1-21.

Kring J.S. 1967. Alighting of aphids on colored cards in a flight chamber. J. Econ. Entomol. 60: 1207-1210.

Leszczyński B. 1987. Mechanizmy odporności pszenicy ozimej na mszycę zbożową Sitobion avenae F. ze szczególnym uwzględnieniem roli związków fenolowych. WSR-P Siedlce, Rozp. Nauk. 21, 97 ss.

Leszczyński B., Warchoł J., Niraz S. 1985. Poziom barwników roślinnych jako wskaźnik odporności pszenicy ozimej na mszyce zbożowe. Ochrona Roślin 5: 5-6.

Lichtenthaler K.N., Wellburn R.A. 1983. Determinations of total carotenoids and chlorophylls a and b of leaf extracts in different solvents. Biochem. Soc. Trans. 603: 591-592.

Łuczak I. 1991. Szkodliwość Mszycy Burakowej (Aphis fabae Scop.) na Buraku Ćwikłowym. Mszyce - ich Bionomia, Szkodliwość i Wrogowie Naturalni. PAN, Warszawa: 31-41.

Łuczak I. 1993. Zasiedlenie czterech odmian szpinaku przez mszycę burakową (Aphis fabae Scop.) w powiązaniu z zawartością barwników liściowych. Zesz. Nauk. AR Kraków, Ogrodnictwo 21: 115-127.

Łuczak I. 1996a. Harmfulness of Aphis fabae (Scop.) to sugar beet cultivars. Aphids and Other Homopterous Insects 5: 119-125. 
Łuczak I. 1996b. Occurrence of Aphis fabae (Scop.) on different sugar beet cultivars. Rocz. Nauk Roln., Seria E - Ochrona Roślin $25(1 / 2): 71-75$

Łuczak I. 1996c. Colonization of different sugar beet cultivars by Aphis fabae (Scop.). Rocz. Nauk Roln., Seria E - Ochrona Roslin $25(1 / 2): 77-82$.

Łuczak I. 2010. Podatność nowych odmian i linii hodowlanych buraka ćwikłowego na zasiedlenie i żerowanie mszycy burakowej (Aphis fabae Scop.). Prog. Plant Prot./Post. Ochr. Roślin 50 (1): 140-143.

Łuczak I., Gawęda M. 1991a. Effect of leaf pigments on black bean aphid (Aphis fabae Scop.) invasion of red beets. Folia Hort. Ann. III/3: $27-37$.

Łuczak I., Gawęda M. 1991b. Development of the black bean aphid (Aphis fabae Scop.) on red beets in relation to the chemical composition of the leaves. Folia Hort. Ann. III/3: 39-48.

Łuczak I., Gawęda M. 1993. The relationships between the chemical composition of sugar beet leaves and the development of black bean aphid Aphis fabae. IOBC/WPRS Bull. 16 (5): 178-184.

Łuczak I., Świderski A., Gaborska M., Mech-Nowak A. 2012. Występowanie i szkodliwość mszycy burakowej (Aphis fabae Scop.) w uprawie marchwi. Prog. Plant Prot./Post. Ochr. Roślin 52 (2): 235-239.

Nottingham S.T., Hardie J. 1989. Migratory and targeted flight in seasonal forms of the black bean aphid, Aphis fabae. Physiol. Entomol. 14 (4): 451-458.

Prokopy R.J., Owens E.D. 1983. Visual detection of plants by herbivorous insects. Annu. Rev. Entomol. 28: 337-364. 